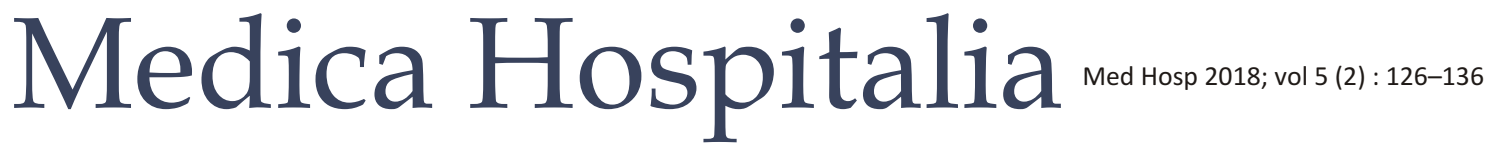

Case Report

\section{Peran MR-Imaging dalam Deteksi Agenesis Corpus Callosum pada Anak dengan Keluhan Kejang}

\author{
Anisah Amalia Waqiati ${ }^{1}$, Frederica Mardiana Wahyuni ${ }^{2}$ \\ ${ }^{1}$ Residen Radiologi Departemen Radiologi Fakultas Kedokteran Universitas Diponegoro/ RSUP Dr. Kariadi Semarang \\ ${ }^{2}$ Konsultan Radiologi Pediatri Departemen Radiologi Fakultas Kedokteran Universitas Diponegoro / \\ RSUP Dr. Kariadi Semarang
}

\begin{abstract}
Abstrak
Latar belakang : Gangguan pada perkembangan otak dapat mengakibatkan abnormalitas. Gangguan tersebut dapat berasal dari beberapa faktor, yaitu faktor lingkungan / didapat, faktor genetik dan abnormalitas fungsional. Kelainan kongenital sistem saraf pusat dapat terjadi sebagai lesi tunggal maupun dapat berhubungan dengan malformasi kongenital yang lain. Neuroimaging memegang peranan penting dalam diagnosa pasien dengan kelainan otak kongenital.

Laporan kasus :

Kasus 1 : Seorang bayi perempuan usia 2 bulan dirawat dengan keluhan kejang yang dirasakan sejak pasien berusia 2 hari. Pada pemeriksaan MRI didapatkan kesan tak tampak gambaran corpus callosum disertai gambaran colpocephale dan pelebaran ventrikel lateral kanan kiri dan ventrikel III membentuk gambaran racing car sign, sesuai gambaran agenesis corpus callosum. Tampak pula adanya heterotopia periventrikuler, microftalmia curiga disertai coloboma cyst dan perineural cyst.

Kasus 2 : seorang anak perempuan usia 10 tahun datang dengan keluhan kejang dan kaku pada seluruh badan. Pada pemeriksaan MRI kepala tanpa kontras didapatkan adanya gambaran colpocephale disertai penipisan body corpus callosum bagian posterior yang mendukung gambaran hipogenesis corpus callosum. Tampak pula gambaran polymicrogyria lobus occipital kanan-kiri dan pachygyria sebagian lobus regio parietal kanan-kiri. Diskusi : Abnormalitas kongenital corpus callosum dapat berupa complete agenesis maupun terbentuk secara parsial / hipogenesis. Diagnosis agenesis corpus callosum sangat bergantung pada neuroimaging. Diagnostik ini dapat ditegakkan pada masa prenatal dan post natal. Pemeriksaan imaging yang dapat digunakan dalam mendiagnosis agenesis corpus callosum adalah ultrasonografi (USG), CT scan dan MRI. Sedangkan pada masa antenatal USG dan MRI merupakan pilihan yang dapat digunakan untuk mendiagnosa adanya agenesis corpus callosum.

Simpulan : Corpus callosum dapat terlihat dengan detail menggunakan pemeriksaan MRI. Pemeriksaan dengan MRI dapat dimulai dari masa fetus sampai lahir. Penegakkan diagnosis sedini mungkin sangat penting dalam penentuan target terapi pasien.
\end{abstract}

\author{
The role of MR imaging in \\ callosal agenesis detection on \\ paediatric seizure
}

\author{
Abstract
}

Background : Disruption of brain development can result in abnormalities. These disruption originated from several factors, namely environmental / acquired factors, genetic factors and functional abnormalities. Congenital abnormalities of central nervous system can occur as a single lesion or can be associated with other congenital malformations. Brain MRI plays an important role in the diagnosis of patients with congenital brain disorders.

\section{Case report :}

Case 1 : Two months baby girl was treated with seizures complaints which felt since the patient was 2 days old. The MRI examination revealed that there was no visible image of the corpus callosum accompanied by colpocephale images and widening of the left right lateral ventricle and ventricle III to form a racing car sign, according to the description of the corpus callosum agenesis. There also appears to be periventricular heterotopia, suspicious microftalmia with coloboma cyst and perineural cyst.

Case 2: a 10-year-old girl comes with spasms and stiffness throughout the body. On plain head MRI examination, we found colpocephale features accompanied by thinning of the posterior corpus callosum body which supports the image of corpus callosum hypogenesis. We also found polymicrogyria of bilateral occipital lobe and the pachygyria in part of the bilateral parietal region lobe.

Discussions : Congenital anomalies of corpus callosum can occur as complete agenesis or partial agenesis / hypogenesis. The diagnosis of corpus callosum agenesis is very dependent on neuroimaging. This diagnostic can be established during the prenatal and post natal period. Imaging tests used in diagnosing corpus callosum agenesis are ultrasonography (USG), CT scan and MRI. While in the antenatal period ultrasound and MRI are options that can be used to diagnose the presence of corpus callosum 
Kata kunci : agenesis callosal, malformasi otak, malformasi kongenital agenesis.

Conclusion : Corpus callosum can be seen in detail by using head MRI examination. Examination with MRI can be started from the fetus to birth. Establishing diagnosis as early as possible is very important in determining the patient's therapeutic targets.

Keywords : callosal agenesis, brain malformation, congenital malformation

\section{PENDAHULUAN}

Gangguan pada perkembangan otak dapat mengakibatkan abnormalitas. Gangguan tersebut dapat berasal dari beberapa faktor, yaitu faktor lingkungan / didapat, faktor genetik dan abnormalitas fungsional. Faktor lingkungan / didapat yang utama berhubungan dengan kehamilan dan proses kelahiran, termasuk faktor yang dapat mempengaruhi fase pre-natal (infeksi maupun hipoksia). Faktor genetik misalnya adalah adanya perubahan dan gangguan di tingkat kromosom. Secara genetik, pembentukan dan perkembangan otak terprogram dan dikendalikan oleh gen 'organizer' dan 'regulator' (up-regulated atau down-regulated). Regulasi yang abnormal gen ini dapat berperan dalam terjadinya malformasi perkembangan sistem saraf pusat. ${ }^{1,2}$

Proses perkembangan abnormal otak dapat menyebabkan displasia ataupun malformasi. Hal ini merupakan penemuan tersering pada pemeriksaan neuroimaging pada anak dengan keterlambatan perkembangan, retardasi mental ataupun epilepsi. Sebagian besar struktur pada otak dibentuk pada saat yang kurang lebih bersamaan.,3 Oleh karena itu, malformasi pada otak sering mengakibatkan anomali pada lebih dari satu struktur. Sebagai contoh malformasi pada perkembangan korteks cerebri dapat berhubungan dengan kelainan pada cerebellum, cephaloceles sering berhubungan dengan heterotopia grey matter atau kelainan corpus callosum, serta holoprosencephali sering berhubungan dengan anomali corpus callosum dan korteks cerebri. ${ }^{1,4,5}$ Diagnosis pada sebagian besar kelainan kongenital otak, terutama agenesis corpus callosum sangat bergantung pada neuroimaging. Pemeriksaan imaging yang dapat digunakan dalam mendiagnosis agenesis corpus callosum adalah ultrasonografi (USG), CT scan kepala dan MRI kepala. Agenesis corpus callosum dapat didiagnosis sejak antenatal yaitu pada masa gestasi 20 minggu (pertengahan trimester kedua) dan setelah kelahiran. Pada masa antenatal USG dan MRI merupakan pilihan yang dapat digunakan untuk mendiagnosa adanya agenesis corpus callosum.2,3,6 Artikel ini bertujuan untuk membahas peran neuroimaging pada kasus brain malformation terutama agenesis corpus callosum dan heterotopia periventrikular.

\section{LAPORAN KASUS}

\section{Kasus 1:}

Anamnesis dan pemeriksaan fisik

Seorang bayi perempuan usia 2 bulan dibawa ke IGD RSUP Dr. Kariadi dengan keluhan kejang. Pasien ini merupakan rujukan rumah sakit daerah. Anamnesis dilakukan terhadap ibu pasien. Ibu pasien mengeluhkan anaknya mengalami kejang sejak berusia 2 hari. Saat kejang bayi tidak demam. Tidak ada trauma kepala sebelumnya. Kejang berlangsung sekitar 30-60 detik, dalam sehari bayi kejang sekitar 4-5x. Pada pemeriksaan fisik didapatkan tanda vital dalam batas normal.

Pasien kemudian dibawa ke rumah sakit daerah untuk dilakukan perawatan. Pasien dirawat selama 1 minggu dan dilakukan pemeriksaan serologi Toxoplasma dan CMV. Dari hasil pemeriksaan didapatkan IgG Toxoplasma $60 \mathrm{IU} / \mathrm{mL}$ (negatif <4, Equifocal 4-8, Positif >8); IgM Toxoplasma 0,246 COI (negatif <0,8; Equifocal 0,8-1,0; positif $>1,0$ ); IgG CMV 27IU/mL (negatif < 4, Equifocal 4-6, Positif >6); IgM CMV 0,194 COI (negatif <0,7; Equifocal 0,7-1,0; positif >1,0). Pada saat di rumah sakit daerah, pasien juga dilakukan pemeriksaan EEG dengan hasil didapatkan gelombang sharp dan spike yang mengarah ke epilepsi. Pada waktu pulang pasien diberi obat kejang berupa sirup yang berisi asam valproat dan puyer. Setelah meminum obat kejang pasien berkurang, kejangnya lebih jarang.

Sepuluh hari sebelum dirujuk ke RSUP Dr. Kariadi, intensitas kejang pasien bertambah. Pasien kejang setiap setengah jam sekali dan sekali kejang sekitar 30 menit. Saat kejang pasien tidak sadar, tetapi sebelum dan sesudah kejang pasien sadar. Awalnya pasien tidak demam tapi kemudian menjadi demam. Intensitas minum ASI berkurang karena sering kejang. Kemudian pasien dibawa ke rumah sakit daerah dan dirawat di ICU selama kurang lebih satu minggu kemudian dirujuk ke RSUP Dr. Kariadi Semarang karena tidak ada perbaikan yang berarti.

Pasien merupakan anak ke dua, lahir spontan dengan dokter spesialis kebidanan dan kandungan. Berat badan lahir sekitar 3000 gram, panjang badan lahir $46 \mathrm{~cm}$. Selama hamil ibu melakukan antenatal care dengan bidan dan dokter spesialis kebidanan dan kandungan. Riwayat ibu sakit saat hamil disangkal. Anak pertama sehat dan perkembangannya normal. Riwayat adanya kelainan kongenital lain pada keluarga disangkal. Kakak pasien 


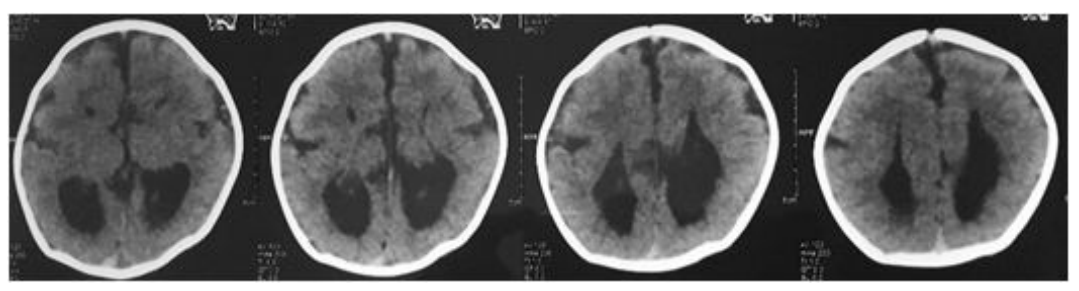

(a)
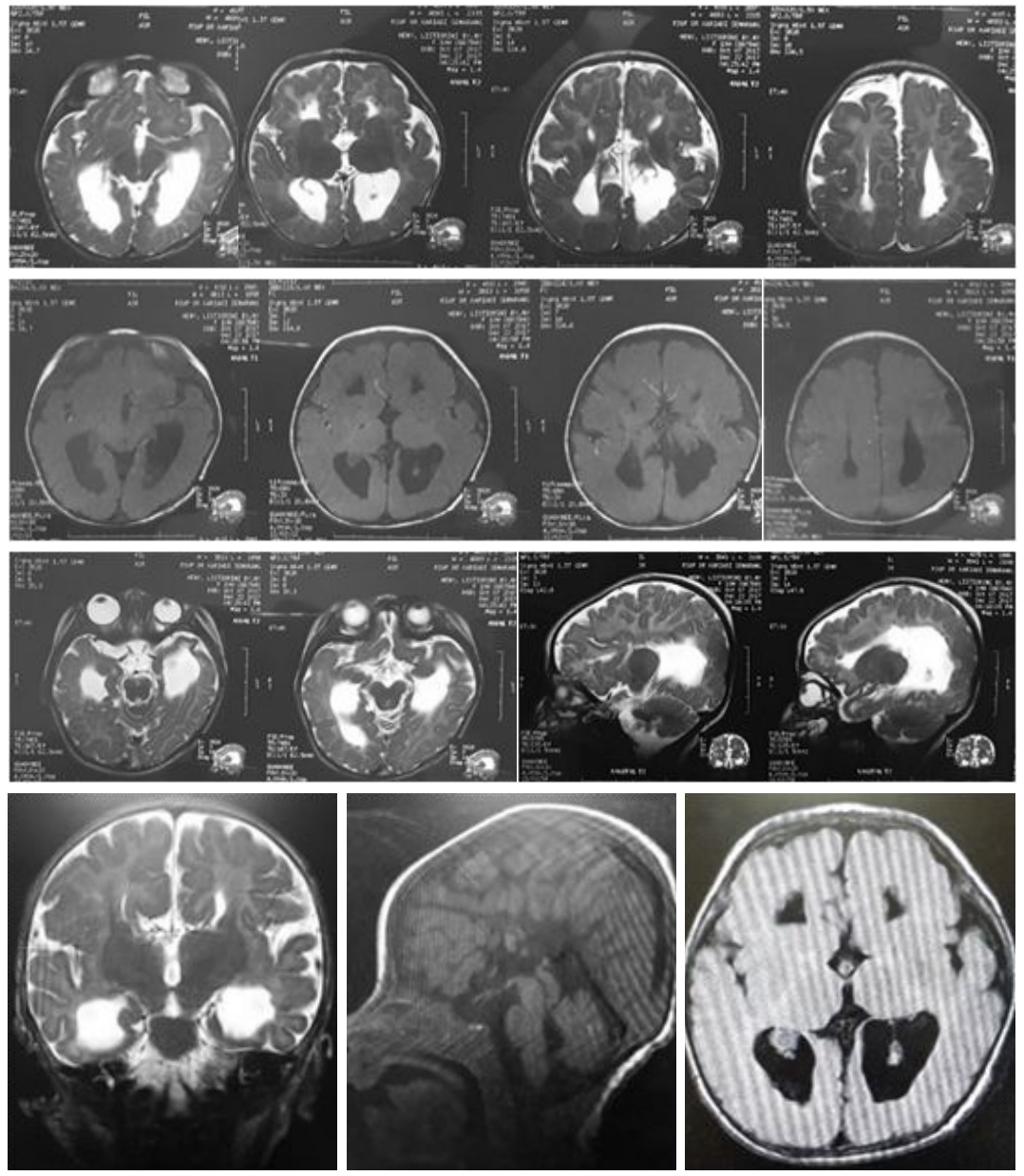

(b)

Gambar 1. Pemeriksaan imaging anak perempuan usia 2 bulan dengan keluhan kejang. Gambar (a) merupakan pemeriksaan MSCT kepala dengan kontras. Gambar (b) merupakan pemeriksaan MRI kepala tanpa kontras sekuen T1WI, T2WI dan T2FLAIR

sehat dengan pertumbuhan dan perkembangan yang normal sesuai usianya.

\section{Pemeriksaan laboratorium}

Di RSUP Dr. Kariadi Semarang dilakukan ulang pemeriksaan Serologi dengan hasil :

\begin{tabular}{|c|c|c|}
\hline & Kadar & Nilai Acuan \\
\hline IgG Toxoplasma & $0,02 \mathrm{IU} / \mathrm{mL}$ & $\begin{array}{l}\text { (negatif <0,54; } \\
\text { Equifocal 0,55 - 0,64; }\end{array}$ \\
\hline IgG Rubella & $20 \mathrm{IU} / \mathrm{mL}$ & $\begin{array}{l}\text { Positif }>0,64 \text { ) } \\
\text { (negatif }<13 \\
\text { Equifocal } 13-15 \\
\text { Positif }>15 \text { ) }\end{array}$ \\
\hline
\end{tabular}

\begin{tabular}{|c|c|c|}
\hline & Kadar & Nilai Acuan \\
\hline IgG CMV & $14 \mathrm{IU} / \mathrm{mL}$ & $\begin{array}{l}\text { (negatif }<0,7 ; \\
\text { Equifocal } 0,7-1,0 ; \\
\text { positif }>1,0 \text { ) }\end{array}$ \\
\hline IgM Toxoplasma & 0,02 IU/mL & $\begin{array}{l}\text { (negatif }<0,54 ; \\
\text { Equifocal } 0,55-0,64 ; \\
\text { Positif }>0,64 \text { ) }\end{array}$ \\
\hline IgM Rubella & $0,1 \mathrm{IU} / \mathrm{mL}$ & $\begin{array}{l}\text { (negatif <13; } \\
\text { Equifocal 13-15; }\end{array}$ \\
\hline IgM CMV & $0,06 \mathrm{IU} / \mathrm{mL}$ & $\begin{array}{l}\text { Positif }>15 \text { ) } \\
\text { (negatif }<0,7 \\
\text { Equifocal } 0,7-1,0 ; \\
\text { positif }>1,0 \text { ) }\end{array}$ \\
\hline
\end{tabular}



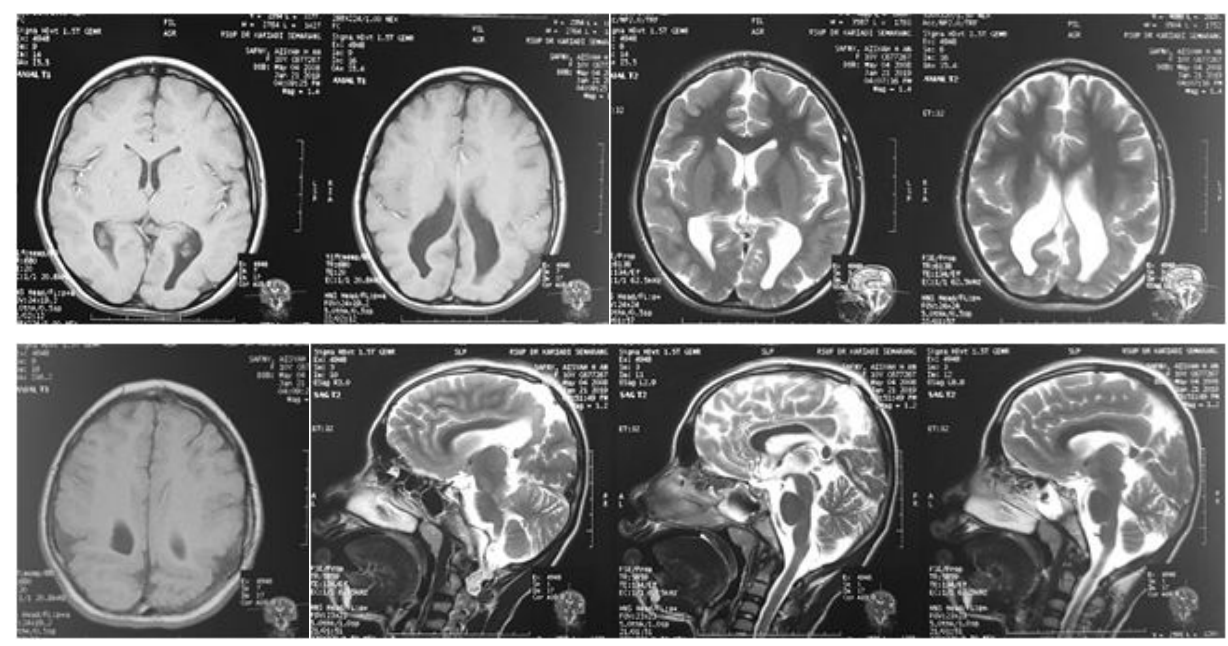

Gambar 2. Pemeriksaan MRI pasien kasus 2

\section{Pemeriksaan Imaging}

Pemeriksaan CT scan dengan kontras pada tanggal 5 Desember 2017 didapatkan kesan gambaran colpocephale cenderung suatu hipoplasia corpus callosum, tak tampak tanda peningkatan tekanan intracranial, tak tampak tanda meningoencephalitis.

Pemeriksaan MRI pada tanggal 22 Desember 2018 didapatkan kesan tak tampak gambaran corpus callosum disertai gambaran colpocephale dan pelebaran ventrikel lateral kanan kiri dan ventrikel III membentuk gambaran racing car sign, sesuai gambaran corpus callosum; Multiple lesi nodular pada periventrikular cornu anterior dan cornu posteror ventrikel lateral kanan kiri, cenderung gambaran periventrikular heterotopia; arteri cerebri anterior kiri tak terbentuk dengan cabang-cabang kecil dari arteri cerebri anterior kanan memperdarahi lobus frontal kiri; Subarachnoid space regio frontal kanan tampak melebar, masih mungkin proses perkembangan; Gambaran microftalmia kiri curiga disertai coloboma; Lesi kistik pada nerve sheath nervus opticus kiri, cenderung perineural cyst.

\section{Kasus 2}

\section{Anamnesis}

Seorang anak perempuan datang ke poliklinik ilmu kesehatan anak RSUP Dr. Karadi Semarang dengan keluhan kejang dan kaku pada seluruh badan. Keluhan kaku dirasakan pada hampir seluruh tubuh, terutama pada tangan sebelah kiri sejak pasien masih bayi. Keluhan kaku dirasakan semakin bertambah sekitar 2 tahun yang lalu disertai dengan kejang pada seluruh tubuh. Tidak ada riwayat panas sebelumnya maupun riwayat trauma kepala sebelumnya.

\section{Pemeriksaan Fisik}

Kepala : mikrosefal

Pupil : isokor $3 \mathrm{~mm} / 3 \mathrm{~mm}$

Thoraks dan abdomen dalam batas normal
Pemeriksaan neurologis didapatkan : pasien tampak spastik

Reflek fisologis meningkat pada keempat extremitas

Reflek patologis pada extremitas bawah

Tonus meningkat pada keempat extremitas

Klonis pada extremitas bawah

Pada pemeriksaan EEG didapatkan sharp wave pada regio temporal kanan dan spike wave pada regio temporal kiri yang dikesankan sebagai fokus epileptogenik pada kedua sisi temporal.

\section{Riwayat Kehamilan dan Persalinan}

Pasien merupakan anak pertama dari seorang ibu yang berusia 18 tahun saat mengandung pasien. Dari anamnesis didapatkan riwayat ibu meminum racun tikus saat ibu usia kehamilan sekitar empat bulan. Pasien lahir dengan persalinan normal dengan berat badan lahir 200 gram dibantu oleh bidan. Pasien langsung menangis setelah lahir.

\section{Pemeriksaan Imaging}

Pemeriksaan MRI kepala tanpa kontras pada tanggal 21 Januari 2019 didapatkan dilatasi trigonum dan cornu posterior ventrikel lateral kanan kiri disertai penipisan body corpus callosum bagian posterior yang merupakan gambaran colpocephaly disertai penipisan body corpus callosum yang mendukung gambaran hypogenesis corpus callosum. Tampak pula polymicrogyria lobus occipital kanan kiri dan pachygyria sebagian lobus parietal kanan kiri, struktur hippocampus normal, tak tampak atropi maupun sklerosis serta ditemukan pula adanya sinusitis maksilaris dan sphenoiditis kanan kiri.

\section{PEMBAHASAN}

\section{Anatomi dan Embriologi Corpus Callosum}

Terdapat tiga buah commisura telencephalic yang berasal dari plate commissura (anterior, callosal dan 


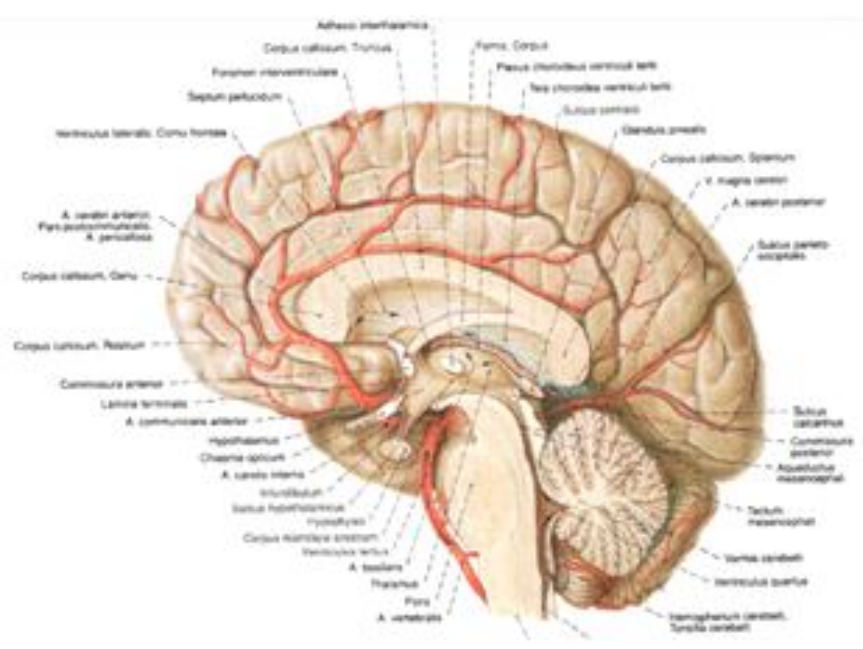

Gambar 3. Potongan sagital corpus callosum
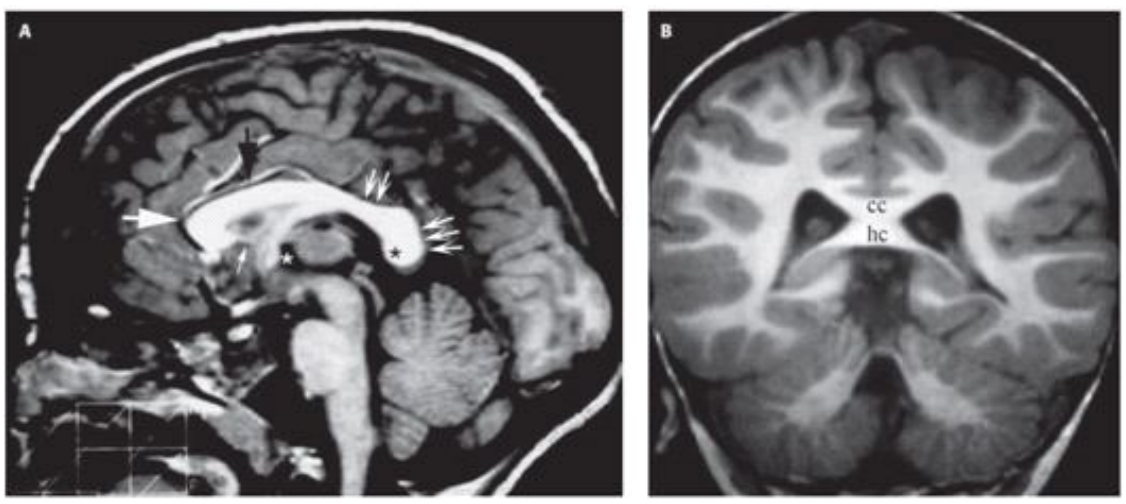

Gambar 4. Commissura cerebral yang normal pada pemeriksaan MRI T1WI. (A) Potongan sagital menunjukkan anterior comissura (tanda * putih) pada bagian atas dari dinding anterior ventrikel III (lamina terminalis). Comissura hipocampal (*hitam) menghubungkan columna forniks dan menyatu dengan splenium corpus callosum di midline. Bagian dari corpus callosum ada rostrum (panah kecil), genu (panah besar putih), truncus (panah besar hitam, istmus (panah putih 2) dan splenium (panah putih 3). (B) Gambar coronal menunjukkan adanya separasi antara corpus callosum yang menghubungkan white matter hemisfer cerebri dan commissura hipocampal yang menghubungkan fornix. ${ }^{2,8}$

hipocampal). Corpus callosum merupakan commissura terbesar dan paling tervisualisasi. Corpus callosum merupakan serat neuron utama interhemiser dan mengandung sekitar 200 juta akson yang merupakan sekitar 2-3\% dari seluruh serat kortikal, sehingga corpus callosum merupakan traktus neuron yang terluas di sistem saraf pusat. 2,3,8,10,11

Corpus callosum dibentuk oleh 5 bagian yaitu rostrum (lamina rostralis), genu, truncus, isthmus dan splenium. Isthmus menghubungkan girus precentral dan girus post central dan mngandung axon termielinisasi dalam jumlah yang banyak. Di anteriornya terdapat truncus, genu dan lamina rostralis yang mengandung axon commissura termielinisasi dalam jumlah yang lebih sedikit yang menghubungkan area asosiasi lobus frontal, korteks premotorik dan korteks prefrontal. Posterior dari isthmus adalah splenium yang mengandung axon dari lobus parietal, occipital medial dan korteks temporal medial. ${ }^{2,3,6}$

Pembentukan corpus callosum dimulai dari minggu ke enam gestasi ketika akson menyilangi midline dan mulai tumbuh pada medial hemisfer. Pada minggu 11-12 gestasi, serat neuron mulai menyebrangi midline melalui commissuralis yang terletak di antara commissur anterior dan commissura hippocampal untuk membentuk corpus callosum. 2,7,10

Pada minggu ke 6 dan 8 gestasi, bagian dorsal lamina terminalis menebal ke dalam lamina reuniens. Bagian rostral kemudian mengalami invaginasi selama minggu ke 8 dan sel-sel bermigrasi ke lekukan invaginasi, pada sulcus medianus telencephali media, membentuk massa commissuralis. Bagian ini kemudian tumbuh ke 
dorsal membentuk alas untuk fiber-fiber corpus callosum. Fiber-fiber tersebut akan menyilangi hemisfer menuju massa commissuralis selama minggu ke-11 gestasi. ${ }^{2,10,11}$

Genu corpus callosum dibentuk pada minggu ke13 gestasi pada regio commissural plate, kemudian proses pertumbuhan terjadi secara progresif ke arah caudal berakhir menjadi splenium.

\section{Epidemiologi}

Insidensi agenesis corpus callosum yang tepat belum ada data yang pasti karena banyak pasien dengan kelainan ini asimtomatik. Angka kejadian agenesis corpus callosus diperkirakan terjadi pada 0,5 sampai 70 orang pada 10.000 kelahiran atau populasi dewasa dan angka ini dapat meningkat pada kasus pediatrik dengan anomali perkembangan yang dapat mencapai 2-3 per 100 kelahiran. ${ }^{4,8,11}$

\section{Patofisiologi Agenesis Corpus Callosum}

Pembentukan corpus callosum terjadi pada minggu ke 6-20 masa gestasional. Periode ini merupakan fase migrasi neuron pada forebrain serta pembentukan cerebelum dan cerebrum pada fase yang sama. Oleh karena itu, anomali pada corpus callosum dapat berhubungan dengan anomali pada cerebrum dan cerebellum seperti malformasi Chiari tipe II, hipoplasia cerebellar, Dandy Walker spectrum, malformasi pada cortical development, cephalocele, malformasi hipothalamus dan anomali midline pada wajah. Meskipun kelainan corpus callosum dapat terjadi sebagai lesi tunggal dan asimtomatik, tetapi lesi yang ditemukan secara insidental sangatjarang. 2,6,9,12

Beberapa sindrom yang berhubungan dengan agenesis corpus callosum antara lain : Sindrom Aicardi, Sindrom Apert, Malformasi Chiari tipe II, Sindrom CRASH, Dandy Walker Malformation, fetal alcoholic syndrome, Displasia frontonasal, sindrom Morning Glory, sindrom Neu Laxova, hiperglikemia non ketotik, defisiensi piruvat dehidrogenase, sindrom oro-fasialdigital, sindrom Rubinstein Taybi, sindrom Shapiro, sindrom Waker Warburg. ${ }^{2}$

Faktor genetik diperkirakan sebagai penyebab utama agenesis corpus callosum. Ada beberapa sindrom dan beberapa gen penyebab sudah dikenali. Faktor eksogenik / lingkungan seperti infeksi antenatal, vaskular atau keracunan, dapat mengakibatkan anomali perkembangan tetapi sangat jarang. Pada agenesis corpus callosus yang berdiri sendiri, interaksi antara faktor genetik dan faktor lingkungan telah dilaporkan. tidak ada tanda dan gejala yang spesifik pada agenesis corpus callosum. Beberapa gejala yang ada biasanya berhubungan dengan abnormalitas pertumbuhan. Pada kasus agenesis corpus callosus yang berdiri sendiri, gejala yang ada dapat berbeda dan bervariasi pada masing-masing individu. Ditemukan juga individu dengan gejala yang ringan dan intelegensi yang normal. $6,7,9$

Abnormalitas corpus callosum biasanya berhubungan dengan banyak sindrom. Ada sekitar 187 sindrom yang berhubungan dengan agenesis corpus callosum. Yang paling sering disebutkan adalah Sindrom Aicardi. Sindrom Aicardi merupakan kelainan $x$-linked cromosom yang hanya terjadi pada perempuan dan ditandai dengan gejala seperti spasme infantil, retardasi mental, agenesis corpus callosum, chorioretinopati, abnormalitas vertebra dan EEG yang abnormal. Beberapa kelainan kongenital dapat terjadi juga seperti kista interhemisferik, cortical dysplasia, gray matter heterotopia, kista fossa posterior, hipoplasia cerebellar dan choroid pleksus papiloma. Lacuna chorioretinal dan coloboma okuler dapat juga ditemukan pada pemeriksaam ophtalmologi serta ditemukan juga adanya delay mielinisasi. $2,3,10$
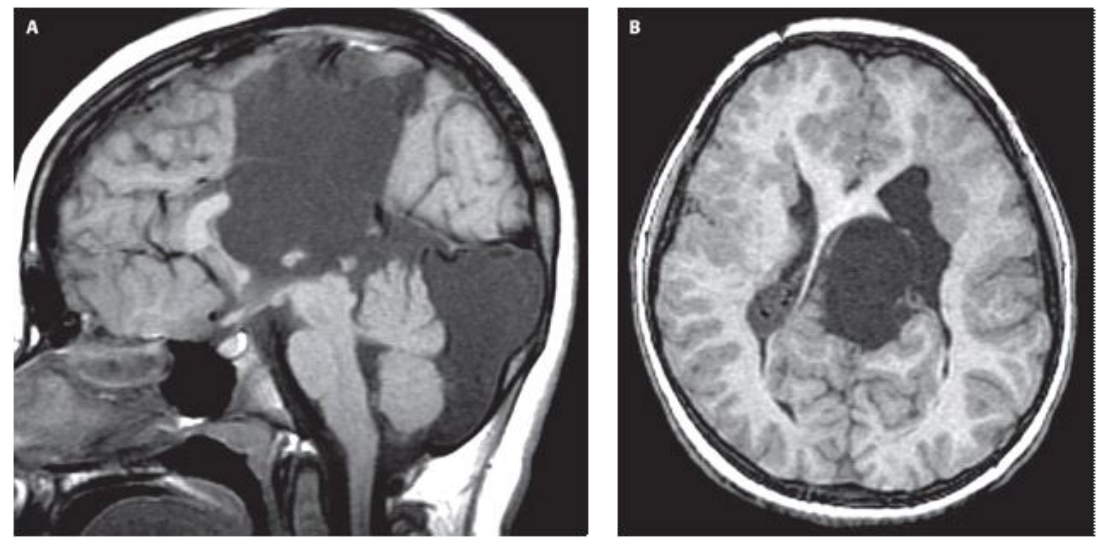

Gambar 5. Sindrom Aicardi. (a) gambaran MRI T1WI potongan sagittal midline pada menunjukkan suatu hipogenesis corpus callosum dengan kista interhemisferik besar dan hipoplasia vermis cerebellum. (b) Pada potongan axial menunjukkan adanya kista interhemisferik dengan subependimal dan subkortikal heterotopia dan displasia korteks pada kedua hemisfer. ${ }^{2,6}$ 

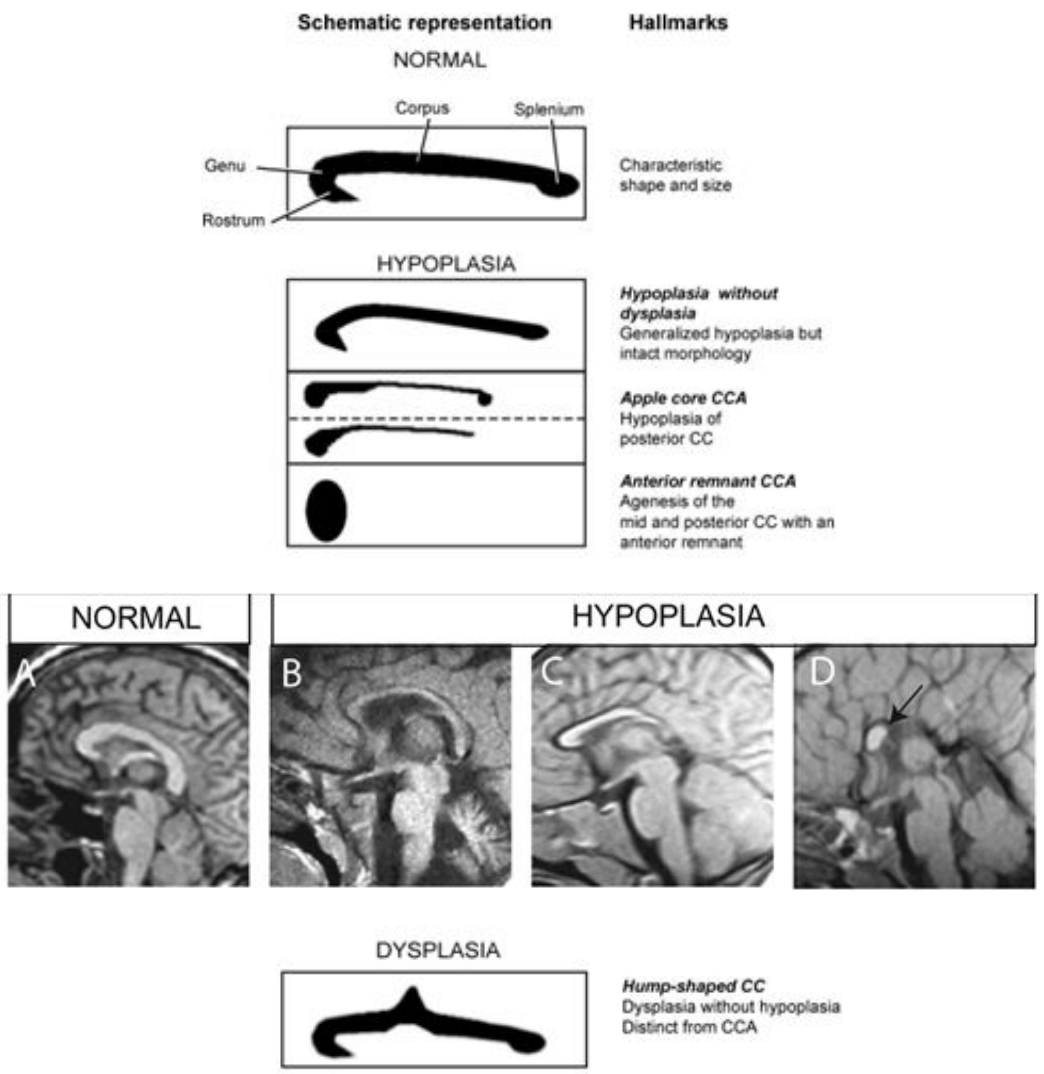

Hump-shoped CC Oysplasia without hypoplasia

HYPOPLASIA with DYSPLASIA

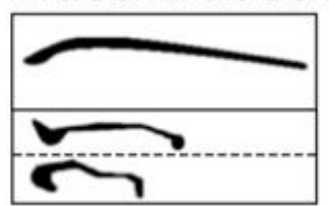

Stripe CCA

Uniformly thinned

CC, with dysplasia

Kinked CCA

Hypoplasia

COMPLETE AGENESIS

and kinked $C$

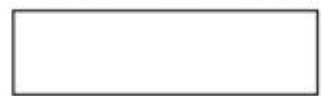

Complete agenesis Completely absent $\mathrm{CC}$ at the resolution of MR
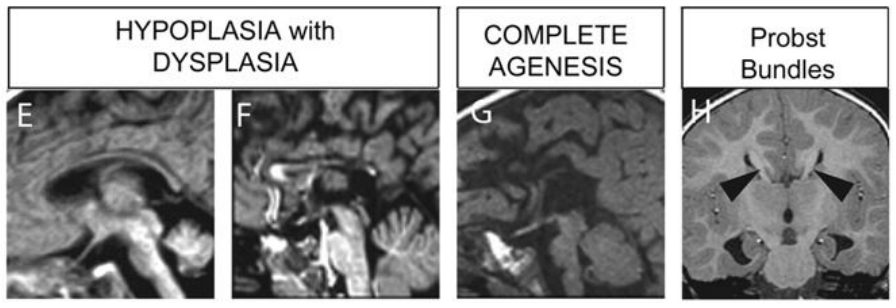

Gambar 6. Klasifikasi gambaran corpus callosum pada pemeriksaan MRI potongan midsagittal. ${ }^{11}$

\section{Klasifikasi Agenesis Corpus Callosum}

Pada corpus callosum dapat terjadi complete agenesis maupun terbentuk secara parsial / hypogenesis. Beberapa bentuk agenesis corpus callosum antara lain:

1. Tak terbentuknya struktur commissura telencephalic.

2. Corpus callosum tidak terbentuk tetapi commissura anterior dan hippocampal telah terbentuk.
3. Pars posterior corpus callosum sebagian tidak terbentuk. Ketika corpus callosum tidak terbentuk, akson tidak dapat melintasi midline karena commissura plate tidak terbentuk. Akson-akson tersebut akan berjalan sejajar dengan fissura interhemisferik membentuk bundle Probst. Bundle tersebut terletak di medial dan menginvaginasi dinding medial ventrikel lateral sehingga dinding medial ventrikel lateral akan berbentuk crescent. 

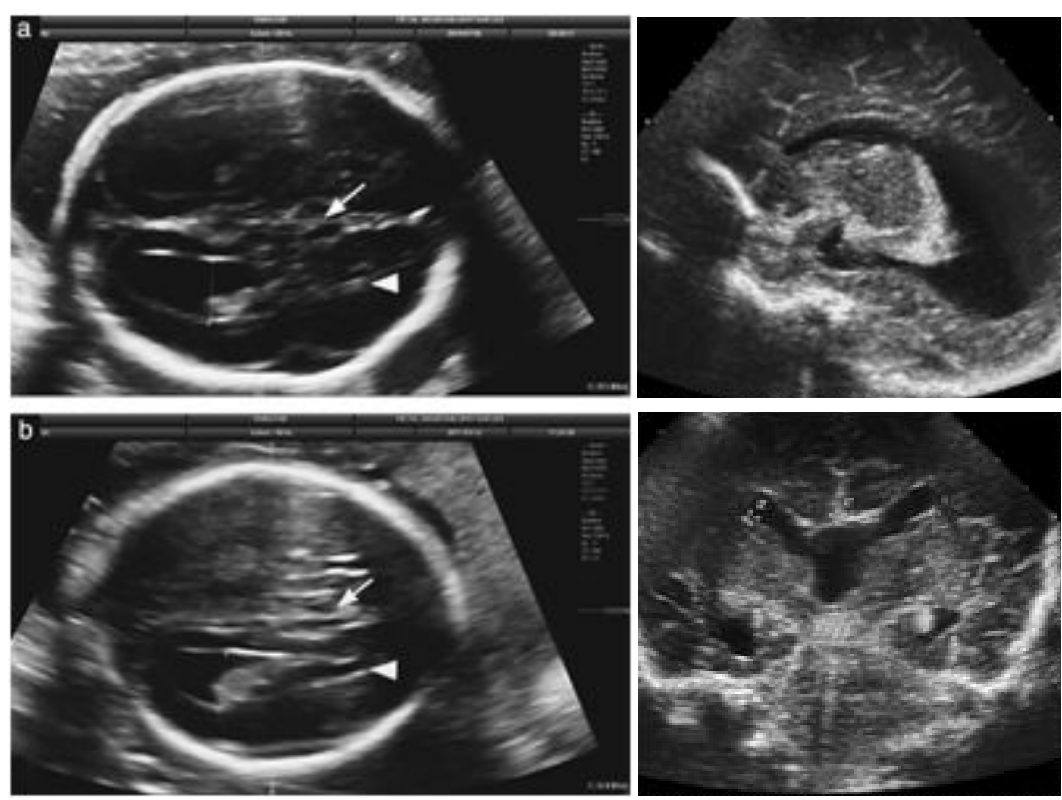

Gambar 7. Pemeriksaan USG fetal pada pasien dengan agenesis corpus callosum pada pasien yang berbeda. Tampak dilatasi pada cornu occipital ventrikel lateral dan tak tampak adanya cavum septum pellucidum. Dengan tanda panah menunjukkan cornu frontal yang sempit. ${ }^{4,6}$

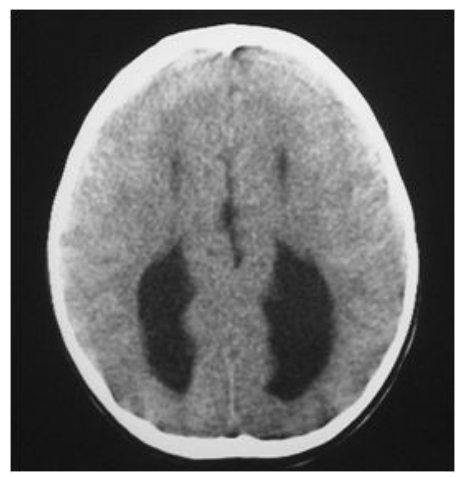

Gambar 8. Agenesis corpus callosum pada pemeriksaan CT tanpa kontras menunjukkan adanya colpocephale yang ditandai dengan adanya dilatasi dari atrium dan cornu occipital ventrikel lateral. Adanya interdigitation gyri pada falk dapat ditemukan secara insidental. ${ }^{3,7}$

Kelainan pada corpus callosum dapat berupa complete agenesis, agenesis parsial, hypogenesis dan dysgenesis / atipikal. Pada complete agenesis corpus callosum, tak tampak struktur corpus callosum. Sedangkan pada pasien dengan agenesis parsial corpus callosum maka bagian anterior corpus callosum telah terbentuk dan bagian posterior corpus callosum tidak terbentuk. Pada hypogenesis corpus callosum, corpus callosum telah terbentuk tetapi ukurannya kecil. Sedangkan dysgenesis corpus callosum terjadi pada keadaan dimana corpus callosum telah terbentuk tetapi strukturnya atipikal. 5,9

\section{Diagnosis}

Gejala klinis yang sering terjadi pada agenesis corpus callosum antara lain : retardasi mental, gangguan penglihatan, keterlambatan bicara, kejang dan gangguan makan, serta gejala-gejala yang berhubungan dengan keterlambatan perkembangan motorik dan bahasa serta gangguan penglihatan, pendengaran, kontraksi muskular juga gangguan psikososial dan kognitif.

Diagnosis kelaianan corpus callosum sangat bergantung pada neuroimaging. Pilihan imaging yang tepat akan sangat bermanfaat pada penegakkan diagnosis pasien. Imaging pada kelainan corpus callosum dapat menggunakan USG, CT atau MRI. ${ }^{7,11,12}$

Pemeriksaan imaging dengan MRI merupakan pilihan utama dalam menentukan diagnosis agenesis corpus callosum. MRI dapat digunakan untuk meliht dengan jelas anatomi corpus callosum sehingga dapat dengan jelas ditentukan apakah terdapat complete agenesis maupun agenesis parsial. 
(a)
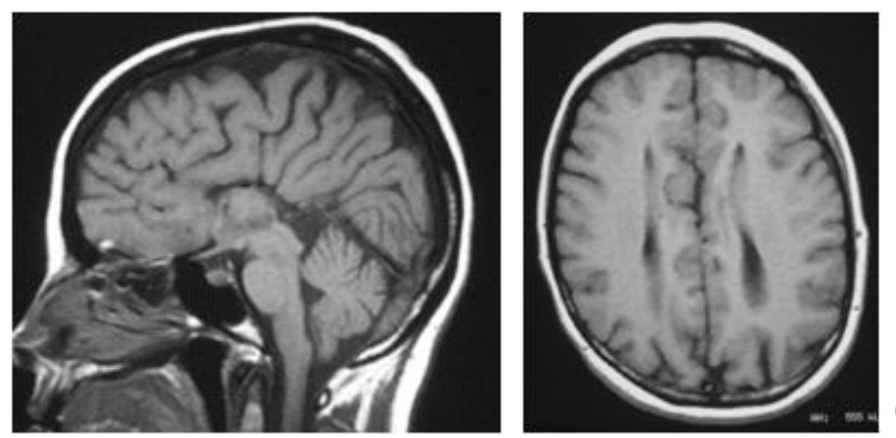

(b)

(c)
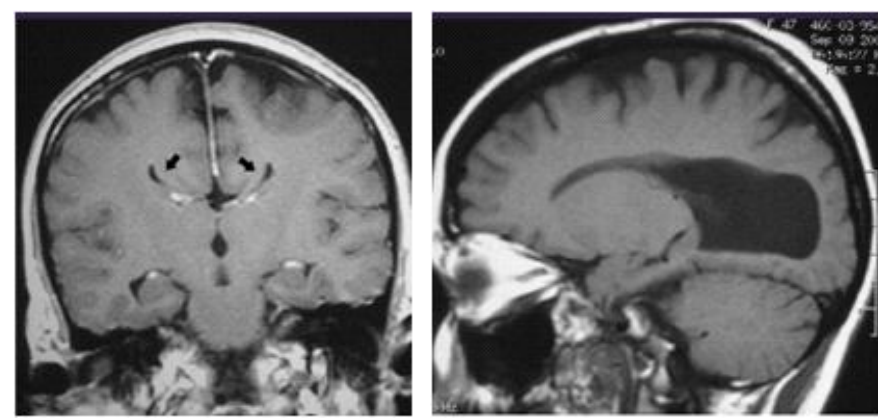

(d)

Gambar 9. Pemeriksaan MRI T1WI pada pasien dengan complete agenesis corpus callosum. (a) Potongan sagittal menunjukkan tak tampak adanya corpus callosum dan girus cingulate. (b) Pada potongan axial menunjukkan bahwa ventikel lateral tampak terletak paralel dan tidak berhubungan satu sama lain. (c) Pada potongan coronal menunjukkan tidak adanya struktur normal corpus callosum. Ventrikel lateral kanan kiri membentuk gambaran bull's horn dan terdapat indentasi pada aspek medial oleh bundle Probst. (d) Pada para sagittal melalui ventrikel lateral menunjukkan dilatasi atrium dan cornu occipital (colpocephaly). ${ }^{2,7}$

(a)

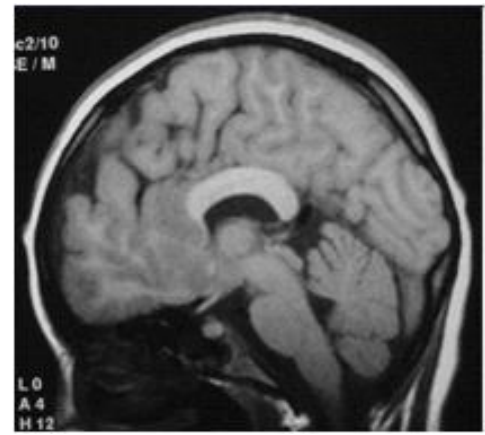

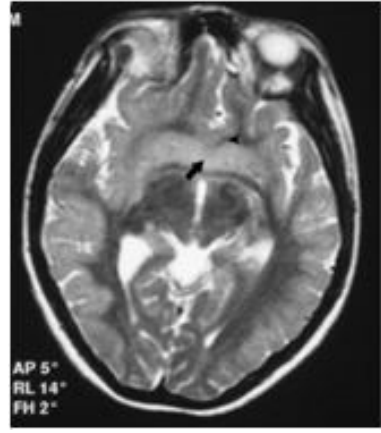

(b)

Gambar 10. Pemeriksaan MRI pada pasien dengan disgenesis corpus callosum pada lobar holoprosencephaly. (a) Pada MRI T1WI potongan sagittal menunjukkan truncus dan splenium corpus callosum telah terbentuk sedangkan genu dan rostrumnya hipoplasia. (b) Pada MRI T2WI potongan axil menunjukkan adanya fusi basal ganglia inferior pada midline dan medial corteks lobus frontal menyilangi fissura interhemisferik. ${ }^{2,9}$

Pemeriksaan corpus callosum dengan USG dapat dilakukan saat diagnosis antenatal, yaitu mulai usia gestasi 20 minggu. Pada saat antenatal USG dapat menganalisa adanya gambaran colpocephaly dan dinding ventrikel lateral yang paralel. Pada bayi dengan fontanella anterior yang belum menutup, skrining dengan USG dapat dengan jelas memperlihatkan absennya corpus callosum. Pada keadaan agenesi corpus callosum, ventrikel III akan tampak high riding di antara ventrikel lateral kanan kiri. Tampak pula bentuk ventrikel lateral kanan kiri yang khas. USG dapat memperlihatkan adanya kelainan penyerta lain seperti kista interhemisferik, hidrosefalus, encephalocele, holoprosencephaly serta anomali lain yang berkaitan. ${ }^{7,9}$

Pada pemeriksaan dengan CT akan didapatkan dinding ventrikel lateral yang paralel, colpocephal serta perluasan ventrikel III ke fissura interhemisferik. Cornu anterior tampak sempit dan corpus ventrikel lateral tampak berbentuk lancip. Pada keadaan di mana tidak terdapat hidrosephalus, frontal horn akan terlihat sempit. 
Sedangkan occipital horns akan tampak lebih dilatasi dibandingkan corpus ventrikel lateral (colpocephaly). Dapat ditemukan pula elevasi ventrikel III dan interposisi antara corpus ventrikel lateral, dimana ventrikel III biasanya membesar. ${ }^{1,5,8}$

Meskipun temuan CT dapat mengarahkan ke agenesis corpus callosum, tetapi gambaran anatomi pada USG dan MRI lebih baik dibandingkan pada CT. MRI merupakan modalitas pilihan pada agenesis corpus callosum baik complete maupun parsial serta untuk menggambarkan adanya kelainan lain yang berhubungan.

MRI merupakan imaging yang paling superior dalam menentukan kelainan corpus callosum, Temuan MRI pada agenesis corpus callosum akan terlihat jelas pada potongan sagittal. Pada T1WI potongan sagittal menunjukkan dengan jelas bentuk disgenesis corpus callosum. Pada complete agenesis corpus callosum maka corpus callosum tidak terlihat. Sedangkan pada hypogenesis corpus callosum maka bagian corpus callosum yang berkembang terakhir yang tidak terlihat. Ventrikel ketiga akan terletak lebih tinggi (high riding), pada posisi di antara ventrikel lateral kanan kiri. ${ }^{2,7}$

Abnormalitas pada proksimal fissura interhemisferik sampai ventrikel III dapat terlihat pada gambaran imaging. Gambaran ini sangat khas sehingga disebut sebagai Interhemisferic fissure sign. Gambaran crescent pada ventrikel lateral merupakan indentasi medial oleh bundle Probst yang tampak pada coronal MRI. Dengan tidak adanya corpus callosum, gyrus pada aspek medial hemisfer akan tampak berada pada atap ventrikel III yang terlihat dengan jelas pada MRI potongan sagital. Dapat pula ditemukan adanya arachnoid cyst interhemisferic yang membuat ventrikel lateral dan III tidak saling berhubungan. ${ }^{2,10}$

Agenesis callosal dengan kista interhemisferik sebagaimana yang ditemukan oleh Barkovich merupakan suatu kondisi yang berbeda dengan agenesis corpus callosum, karena etiologinya berbeda. Ada 2 tipe agenesis callosal dengan kista interhemisferik. Pada tipe 1, kista interhemisferik merupakan suatu divertikulum dari sistem ventrikel yang berhubungan dengan ventrikel. Sedangkan pada tipe 2 , terdapat kista multiple yang tidak berhubungan dengan sistem ventrikel, keadaan ini sering kali berhubungan dengan heterotopia subcortical. 2,8

\section{Penatalaksanaan}

Penatalaksaan pasien dengan anomali corpus callosum dilakukan sesuai gejala yang tampak. Bila mengalami keterlambatan motorik dapat dilakukan terapi fisik, tergantung tingkat keterlambatan motoriknya. Diagnosa tepat sedini mungkin sangat diperlukan dalam perencanaan penentuan target terapi kepada pasien dan keluarga. Edukasi keluarga juga sangat diperlukan karena pasien dengan agenesis corpus callosum memerlukan terapi dan follow up rutin jangka panjang. ${ }^{13}$

Pada pasien dengan hidrosefalus dapat diobati dengan pemasangan VP shunt untuk mengalirkan cairan dari rongga ventrikel sehingga menurunkan tekanan intracranial. Pada pasien dengan keluhan kejang maka dilakukan pengendalian kejang dengan terapi farmakologis. hampir semua obat antiepilepsi lama dan baru telah digunakan. Biasanya diperlukan obat antiepilepsi multiple, namun dapat muncul juga berbagai komplikasi toksisitas dan efek samping. Kortikosteroid, asam valproat, benzodiazepin, dan vigabatrin digunakan untuk infantile spasms. Phenobarbital, phenytoin, carbamazepine, lamotrigine, maupun topiramate untuk kejang parsial. Monitoring kadar obat dalam serum, toksisitas ke hepar dan hematologi harus dilakukan. Konseling genetik juga mungkin bermanfaat untuk keluarga dengan mengalami gangguan ini. ${ }^{11,13}$

\section{SIMPULAN}

Corpus callosum merupakan jaras utama yang menghubungkan serat saraf dari 2 hemisfer cerebri. Anatomi dan embriologi dari commisura ini telah diteliti secara luas. Perkembangan corpus callosum terjadi pada minggu ke 10 hingga minggu ke 20 masa gestasi.

Kelainan corpus callosum dapat terjadi isolated serta dapat berhubungan dengan anomali kongenital yang lain seperti malformasi Chiari tipe II, hipoplasia cerebellar, Dandy Walker spectrum, malformasi pada cortical development, cephalocele, malformasi hipothalamus dan anomali midline pada wajah. Agenesis corpus callosum juga berhubungan dengan banyak sindrom kongenital.

Corpus callosum dapat terlihat dengan detail menggunakan pemeriksaan MRI. Dengan MRI, pemeriksaan dapat dimulai dari masa fetus sampai lahir, berkenaan dengan emriologinya serta tipe dan derajat anomali corpus callosum dan anomali lain yang berhubungan. Penegakkan diagnosis sedini mungkin dalam menentukan perencanaan dan target terapi.

\section{DAFTAR PUSTAKA}

1. Schell-Apacik, Wagner K, Bihler M, Wagner B, Heinrich U, Klopocki E et al. Agenesis and Dysgenesis of the Corpus Callosum : Clinical Genetic and Neuromaging Findings. Am J Med Genet A. 2008 October 1; 146A(19): 2501-2511. doi:10.1002/ajmg.a.32476.

2. Barkovich J, Raybaud C. Pediatric Neuroimaging $5^{\text {th }}$ Edition. Philadelphia. Lippincott Williams and Wilkins; 2012.

3. Markovic I, Milenkovic Z. Agenesis Corpus Callosum : Magnetic Resonance Imaging In Antenatal And Postnatal Cases. Pediatr Neonatol. 1(2). RPN.000506. 2017. DOI: 10.31031/RPN.2017.01.000506

4. Neal, Jasson Bennet. Morphometric Variability of Neuroimaging Features in Children With Agenesis Of The Corpus Callosum. BMC Neurology (2015) 15:116

5. Comstock. 2001. Agenesis of The Corpus Callosum in the Fetus. 
Ultrasound Re Obstetric Gynecology 2001;1:38-44

6. Roy E, Hague C, Forster B, Colistro B, Andrews G. The Corpus Callosum : Imaging the Middle of the Road. Canadian Association of Radiologists Journal 65 (2014) 141e147. http://dx.doi.org/10.1016/j.carj.2013.02.004

7. Aribandi M. Imaging in Agenesis of the Corpus Callosum. 2018. http:/ / emedicine.medscape.com/article/407730-overview

8. Ho Mai-Lan, Moonis G, Ginat D, Eisenberg R. Lesions of the Corpus Callosum. American Roentgen Ray Society. AJR 2013; 200:W1W16.DOI:10.2214/AJR.11.8080

9. Slovis T, Bloom D, Adler B, Bulas D, Coley B, Donaldson J etal. Caffey's Pediatris Diagnostic Imaging $11^{\text {th }}$ Edition. Philadelphia. Mosby Elsevier; 2008.

10. Krupa K, Beklesinska M. 2013. Congenital and Acquired Abnormalities of the corpus callosum : a Pictorial Essay. Hindawi Publishing Corporation. Volume 2013, Article ID 265619, http://dx.doi.org/10.1155/2013/265619.
11. Kulak P, Goscik E, Kuzia J. Abnormalities Corpus Callosum : Magnetic Resonance Imaging analysis in children. Prog Health Sci 2012, Vol 2, No 2 : Abnormalities corpus callosum: Magnetic resonance imaging children

12. Radhouane A, Khaled N. Corpus Callosum Agenesis : Role of fetal magnetic resonance imaging. Asian Pacific Journal of Reproduction, 2016;5(3);263-265

13. Chiappedi M, Bejor M. Corpus Callosum agenesis and rehabilitative treatment. Italian Journal of Pediatrics 2010, 36-64. http://www.ijponline.net/content/36/1/64 